Кожушко Л. Ф. [1; ORCID ID: 0000-0002-5724-4773], д.Т.н., професор кафедри менеджменту

Щербакова А. C. ${ }^{[1 ; 0 R C I D ~ I D: ~ 0000-0003-0972-821 X], ~}$ к.е.н., доцент кафедри менеджменту

${ }^{1}$ Національний університет водного господарства та природокористування, м. Рівне

\title{
ЛІДЕРСТВО ЯК ПЕРЕДУМОВА ЕФЕКТИВНОЇ СИСТЕМИ МЕНЕДЖМЕНТУ ОРГАНІЗАЦІї
}

В статті обґрунтовано, що лідерство є тим видом діяльності, який пронизує всю систему управління та допомагає досягти високої ефективності в діяльності організації. В статті проведений критичний аналіз підходів до визначення поняття «лідерство». Запропоновано авторське визначення поняття «лідерство менеджера». Авторами підкреслено, що при дослідженні впливу лідерства на ефективність роботи організації, доцільно застосовувати поняття «управлінське лідерство». Запропоновано концепцію ефективності управлінського лідерства та доведено, що ефективність управлінського лідерства, що $є$ основою ефективності діяльності організації, визначається здатністю планувати і здійснювати зміни у відповідності з перспективними ідеями і цілями.

Ключові слова: лідер; лідерство; менеджмент; організація; лідерство менеджера; управлінське лідерство; ефективність.

Постановка проблеми. У світлі наявних тенденцій сучасного суспільного розвитку - глобалізації, демократизації, інформатизації зосередження уваги на ролі особистості набуває нового значення. Так, ефективне управління сприяє стабільності і порядку, розв'язанню різноманітних проблем, пов'язаних з життєдіяльністю, а такі поняття, як лідерство і керівництво, безперечно, тісно пов'язані 3 процесом управління. На сьогоднішній день, формування нової управлінської парадигми - лідерства - проявляється через утвердження нових організаційних структур, моделей поведінки, процедур, принципів і цінностей як основи управлінської діяльності. Саме тому менеджмент організацій, лідерство та керівництво стають об'єктами досліджень багатьох учених, адже саме від них залежить успішність будь-якої організації. Саме на розвиток лідерства сьогодні спрямовуються зусилля у багатьох країнах світу як розвинених, так і тих, що прагнуть посилити свою конкурентоспроможність на міжнародній арені. Лідерство розвивають як у приватному, так і 
публічному секторах. Компанії приводяться в рух не логікою, а переконаними людьми, що діють у відповідному культурному та історичному контексті. Вони управляються людиною, що прямує своїм шляхом, використовуючи свої розумові можливості, ділові якості, інстинкти та емоції. Саме тому, проблеми лідерства $\epsilon$ ключовими для підвищення ефективності менеджменту організацій. Керівник повинен бути лідером і вміти мотивувати працівників на повноцінну роботу та досягнення високих результатів.

Аналіз останніх досліджень і публікацій свідчить про те, що тема керівництва і лідерства постійно знаходиться в полі зору іноземних та вітчизняних вчених. Значний внесок в дослідження сутності поняття «лідерство» та розкриття теорій лідерства внесли такі зарубіжні та вітчизняні науковці як П.Друкер, Р.-Л.Дафт, Дж. Террі, Р. Танненбаум, І. Вешлер, Ф. Масарик, О. Евтихов, В. Б. Балдер, Л. Джуелл, Дж. Л. Гібсон, Дж. В. Нюстром, К. Девіс, Р. Стогдилл, Кузес Джеймс М. та інші. Проте, на нашу думку, більшість робіт зачіпають проблеми психології лідерства та потребують більш детального дослідження питання впливу лідерства на ефективність та результативність діяльності підприємства з позиції менеджменту організації.

Постановка завдання. Метою статті $\epsilon$ узагальнення накопиченого досвіду щодо сутності лідерства, а також обґрунтування його впливу на ефективність діяльності організації.

Викладення основного матеріалу. Найбільш серйозною проблемою теорії і практики менеджменту $є$ проблема підвищення якості управління сучасними організаціями. Загостренню конкуренції між організаціями сприяють інтелектуальні перетворення, глобалізація і перехід ряду країн на постіндустріальний етап розвитку. Інформатизація деяких аспектів життєдіяльності, розвиток технологій, інтернаціоналізація економічних зв'язків безпосередньо також впливають на стан системи менеджменту організації [1, С. 93]. Так, одні організації досягають успіху та інтегрують, виходячи на світовий ринок, чи розширюють сферу діяльності, тим самим збільшуючи свій капітал, проте є компанії та організації, які перебувають у занепаді чи ще гірше на грані банкрутства. В цих умовах підприємства особливо гостро потребують постійного вдосконалення системи менеджменту організації для досягнення високих показників ефективності господарської діяльності та забезпечення конкурентоспроможності на ринку. У зв'язку з цим необхідна робота злагодженої команди, яка можлива лише за наявності лідера, який координує роботу свого колективу. 
Проблеми лідерства ключові для досягнення організаційної ефективності. 3 одного боку, лідерство розглядається як наявність певного набору якостей, притаманних тим, хто успішно впливає на інших, з іншого, лідерство - це процес несилового впливу у напрямку досягнення організацією своїх цілей. Для того, щоб складна організація ефективно виконувала свої завдання, необхідно забезпечити виконання всіх функцій менеджменту. Лідерство $€$ тим видом діяльності, який пронизує всю систему управління. Неможливо ефективно виконувати функції планування, організації, мотивації і контролю, якщо немає ефективного керівництва і лідерів, здатних заохочувати інших працівників, позитивно впливати на них $\mathrm{i}$ вести за собою, тим самим досягаючи сприятливих кінцевих результатів [2].

Сучасне розуміння лідерства, будучи продуктом (результатом) тривалої еволюції, так званих, класичних теорій лідерства, передбачає інтеграцію всіх попередніх підходів, методів і способів впливу на людей, поєднуючи з конкретною ситуацією, що дозволяє трактувати лідерство не тільки як науку, а й як мистецтво (тобто практику) менеджменту. Менеджмент використовує лідерство як один $з$ механізмів інтеграції групової діяльності для досягнення цілей організації і характеризує специфічну форму управлінських відносин в групі. Теорія лідерства покликана давати відповідь на багато запитань управління: наприклад, чи $\epsilon$ певні якості, які роблять менеджерів ефективними лідерами; чи лідерами народжуються лідерами, чи дійсно лідерство - навичка, якій менеджер може і повинен навчитися; чи можливо управляти лідерством в організації тощо.

На сьогоднішній день залишається проблемою відсутність універсального визначення базових понять «лідерство», «лідер» та «лідерство менеджера». У процесі вивчення проблеми лідерства вчені запропонували багато різних визначень цього поняття. Цей факт добре ілюструє, наскільки складна природа цього поняття. Розуміння феномена лідерства характеризується складністю, різноманітністю і мінливістю, тому воно не допускає будь-якого уніфікованого визначення. Множинність визначень поняття «лідерство» обумовлено різними підходами до аналізу його предмета. У своїх визначеннях лідерства чимало авторів намагалося чітко сформулювати той особливий компонент, що його вносить сам лідер.

Так, Р.-Л. Дафт [2] трактує лідерство як взаємовідносини між лідером і членами групи, які чинять вплив один на одного i спільно прагнуть реальних змін і досягнення результатів, що 
відбивають загальну мету. Дж. Террі [3] вважає, що лідерство це вплив на групи людей, який спонукає їх до досягнення спільної мети. Р. Танненбаум, І. Вешлер та Ф. Масарик [4] визначають лідерство як міжособистісну взаємодію, яка виявляється в конкретній ситуації на основі комунікативного процесу і спрямована на досягнення мети.

Американський вчений Б. Балдер [2] висловлює думку, що лідерство - це «ярлик», який наклеюють на поведінку інших людей. Тут потрібна віра в те, що якість, котра визначається як лідерство, спричинює певну поведінку. Л. Джуелл [5] вказує на те, що люди вкладають різний зміст у поняття «лідерство»: для одних лідерство означає, що люди за кимось слідують; для інших лідерство означає, що люди залюбки за кимось слідують; для третіх сутність лідерства полягає в тому, що вплив лідерства сприяє ефективному досягненню цілей, але при цьому виникає питання про те, який характер таких цілей (позитивний чи негативний). Авторка говорить про те, протягом десятиріч організаційні психологи та інші спеціалісти, які вивчали лідерство, давали йому різне визначення: сконцентрованість групових процесів; індивідуальність людини та ії вплив; мистецтво добиватись згоди; здійснення впливу; модель поведінки; форма переконання; власні стосунки та ін. Л. Джуелл у своєму дослідженні виходить 3 того, що сутність організаційного лідерства полягає в перевазі фактору впливу над механічним виконанням правил, які прийняті в організації. На думку автора, це визначення передає всі означені вище ідеї лідерства. І особливість лідерства полягає в тому, що лідери спонукають людей робити більше, якби вони робили в разі відсутності лідера, i ці зусилля узгоджуються із цілями організації. Лідерство спонукає людей виходити за рамки простої згоди із системою і допомагає групам у досягненні їх цілей.

Дж. Л. Гібсон [6] зазначає, що, попри те, що поняття «лідерство» вивчається вченими протягом десятиріч, ця проблема до сьогодні має відтінок таємничості, оскільки навіть після проведення багатьох досліджень експерти не прийшли до консенсусу стосовно точного визначення лідерства. Автор, аналізуючи сутність лідерства, детальніше, на нашу думку, розглядає зміст лідерства в контексті здійснення впливу, оскільки говорить про суттєву характеристику впливу лідера, яка полягає в тому, що лідер використовує засоби впливу, які не примушують людей здійснювати певні дії. При цьому особливо наголошується, що лідерство має місце в певному колективі лише тоді, коли певна людина впливає на своїх підлеглих, 
і вони виконують їі прохання без будь-якого зовнішнього вияву влади з їі боку. При цьому лідер, маючи здатність здійснювати вплив, створює і використовує владу і повноваження, які надані його підлеглими. Дж. В. Нюстром, К. Девіс [7], аналізуючи лідерство, говорять про те, що лідерство $€$ важливою складовою управління, яка полягає у здійсненні спрямованого на людей впливу, мета якого - у спонуканні їх до руху до певних цілей (переважно із творчим підйомом). Можна говорити, що у цьому визначенні появляється ще один важливий аспект лідерства - забезпечення ролі творчості працівників при досягненні певних цілей.

На сучасному етапі під лідерством розуміють різні соціальні процеси взаємодії лідера і групи. Наприклад, П. Шрісхайн під лідерством має на увазі процес соціального впливу, де підлеглі і лідер добровільно беруть участь в діяльності по досягненню організаційних цілей. Р. Стогдилл говорить про те, що лідерство - це процес здійснення впливу на групову активність, спрямований на досягнення цілей. Ф. Фрідлер розглядає лідерство як конкретні дії лідера по координації і управлінню діяльністю групи [8].

Сутність поняття лідерства в дослідженнях 3 менеджменту полягає в управлінській взаємодії (в даному випадку між лідером і послідовниками), заснованій на найбільш ефективному для даної ситуації поєднанні різних джерел влади і спрямованій на спонукання людей до досягнення загальних цілей. На нашу думку, лідерство створює унікальну корпоративну культуру і формує образ майбутнього компанії, що забезпечує підтримку цінностей і сприяє ефективній реалізації стратегії. На думку Кузес Джеймса М. [9], роль лідера вкрай важлива на всіх етапах розвитку організації і відводиться керівнику (менеджеру). Так, ідеальною буде ситуація, коли менеджер (керівник) є ще і лідером. Керівник інтегрує якості лідера з якостями менеджера і реалізує їх в організації. В результаті, підвищується ефективність роботи всієї організації, а також кожного співробітника окремо.

Проте, необхідно відрізняти лідера від менеджера (керівника) в організації. Менеджер, як правило, вибудовує таку систему взаємин 3 підлеглими, яка базується на владі та їі джерелах. Лідерство насамперед ґрунтується на певному управлінському типі взаємодії, що виникає в процесі соціального впливу лідера на групу, при цьому не обов'язково присутня посадова система. Цей процес дещо складніший та передбачає наявність послідовників лідера, а не його підлеглих.

Враховуючи все вищенаведене, на нашу думку, можна запропонувати авторське бачення поняття «лідерство менеджера», 
тобто процес, в ході якого менеджер як лідер організації, для досягнення іiї цілей разом з їі співробітниками створює загальне їх бачення майбутнього і організовує взаємодію, а також залучає співробітників організації в реалізацію даних цілей. Дане визначення $є$ більш демократичним і процесуальним, порівняно із існуючими, а також підкреслює залученість співробітників і наявність зворотних зв'язків, що має істотне значення для практики менеджменту організацій.

При дослідженні впливу лідерства на ефективність роботи організації, доцільно застосовувати поняття «управлінський лідер». Так, на нашу думку, управлінський лідер - індивід, що гармонійно поєднує в собі лідерські та менеджерські якості. Як менеджер, управлінський лідер реалізує свої законні повноваження і статусну владу для ефективного вирішення організаційних задач, а як лідер він використовує силу особистісного впливу на підлеглих. Управлінський лідер за своїм статусом $€$ керівником. Це той «ідеальний тип» керівника, що поєднує в собі лідерські та менеджерські якості [10]. Управлінське лідерство проявляється, перш за все, як процес вдосконалення організаційної культури, що дозволяє розвивати елементи, які в своїй сукупності забезпечують ефективну діяльність компанії по реалізації стратегічних цілей. Відносини лідерства присутні на всіх рівнях компанії. Ці контакти відображають сформоване співвідношення індивідуальних сил, влади і впливу на процеси міжособистісного спілкування та організаційної діяльності. Феномен управлінського лідерства виникає тоді, коли підлеглі визнають авторитет і вплив свого керівника не тільки по праву статусної влади, скільки по праву сили його особистості. Управлінський лідер має можливості використання таких ресурсів організації, які недоступні менеджерам-нелідерам або неформальним лідерам груп у складі компанії.

Таким чином, управлінський лідер має більше можливостей для ефективного управління компанією, ніж просто менеджер або неформальний лідер, який не має статусної влади. Ефективність управлінського лідерства безпосередньо обумовлена ефективністю організаційної діяльності. Концепція ефективності управлінського лідерства може стати основою для практичного використання 3 метою підвищення ефективності діяльності конкретних управлінських лідерів (рисунок).

Пізніші дослідження у сфері лідерства показали, що в ефективності керівництва вирішальну роль можуть відіграти додаткові, ситуативні чинники: потреби і особисті якості підлеглих, характер завдання, вимоги і вплив середовища, інформація та ін. 
Крім того, ефективного керівника-лідера 3-поміж інших вирізняє певна система якостей: творча обдарованість, високий рівень інтелекту, харизматичність, ініціативність, упевненість у своїх силах та ін. [11]. Сфера впливу неформального лідера може виходити за адміністративні межі формальної організації. Чинники, що визначають можливість стати лідером, такі: вміння користуватися владними повноваженнями, професійна компетентність, організаційні здібності, високі моральні якості, харизматичний вплив та інші якості і можливості. Особливо важливою складовою психологічної структури особистості лідера $\epsilon$ спроможність раціонально використовувати надану владу.

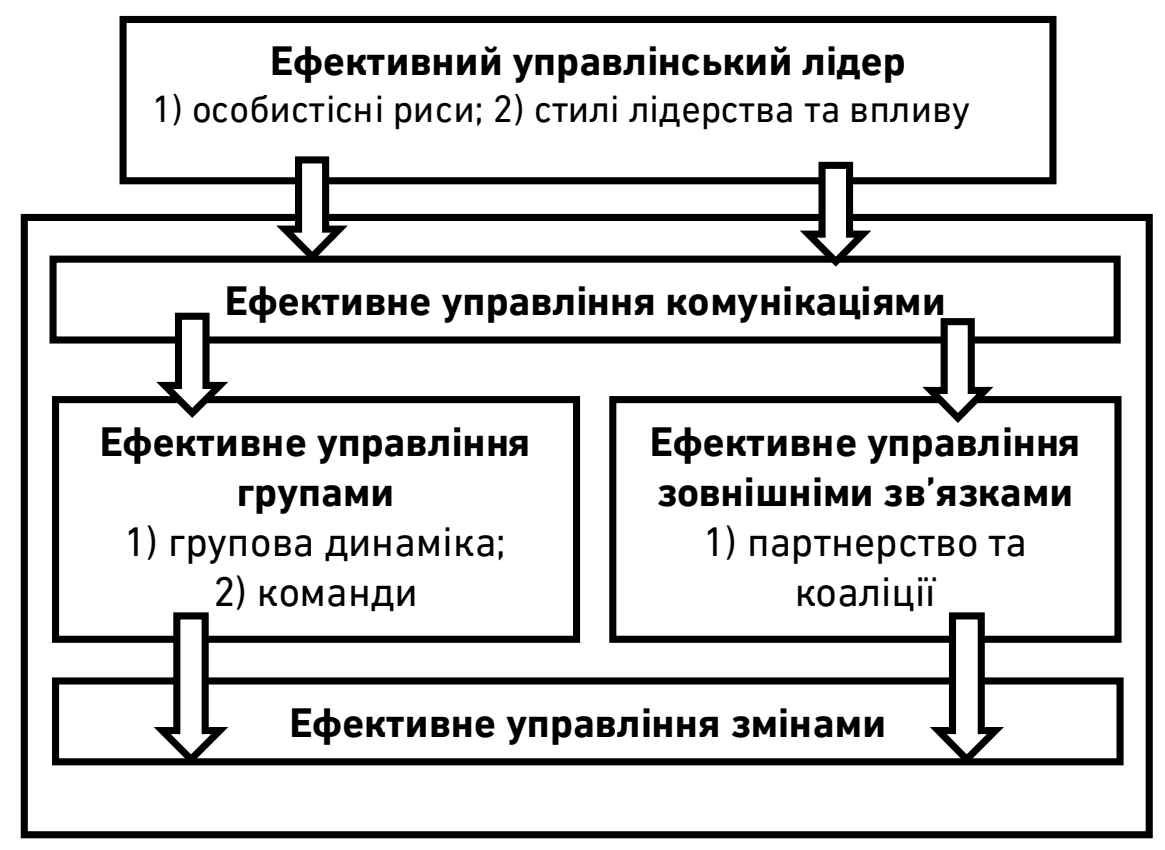

Рисунок. Концепція ефективності управлінського лідерства

Практика показує, що жоден чинник не забезпечує більшу вигоду і користь для організації, ніж ефективне лідерство. Лідери потрібні для визначення цілей і завдань для організації, координації, забезпечення міжособових контактів 3 підлеглими i вибору оптимальних, ефективних шляхів вирішення тих або інших проблем. Очевидно, що організації, де є явні лідери, можуть досягти всього цього набагато швидше, ніж організації без лідерів. Рівень конкурентоспроможності сучасного підприємства безпосередньо залежить від здібностей людей, які здійснюють координацію діяльності в організації, використовувати власний ресурс. Керівники різних підрозділів сучасного підприємства формують загальне 
уявлення про організацію. Багато що залежить від рис характеру i особистих якостей, тих, хто займає керівні посади. За рівнем діяльності сучасного підприємства можна судити про керівництво цього підприємства.

Ефективність менеджменту організацій безпосередньо пов'язана з оптимальним використанням ресурсів організації при вирішенні насущних проблем і їі здатністю гідно зустріти вимоги найближчого майбутнього (з розрахунку на нові досягнення). У стабільній ситуації ефективність функціонування організації може бути забезпечена менеджментом без урахування відносин лідерства. Але в нестабільних умовах, постійній готовності до змін відповідно до нових обставин і запитів, ефективність організаційної діяльності залежить від потенціалу лідерства.

Ефективність управлінського лідерства, що $€$ основою ефективності діяльності організації, визначається здатністю планувати і здійснювати зміни у відповідності з перспективними ідеями і цілями. Ефективний управлінський лідер повинен вміти долати опір змінам. Специфіка управлінського лідерства визначає особливості оцінки його ефективності. Модель оцінки ефективності управлінського лідерства багато в чому залежить від його вміння вибудувати організаційну структуру і від процедур, що забезпечують результативність діяльності [12].

Оцінка ефективності організаційної діяльності багато в чому базується на управлінських здібностях лідера і має дві складові: 1) об'єктивні - кількісні та якісні показники роботи, результативності компанії і рішень керівництва; існуючі технології оптимальної діяльності по досягненню конкретної мети, міжнародні та національні стандарти цієї діяльності; 2) суб'єктивні - сприйняття управлінським лідером, підлеглими та іншими зацікавленими особами результативності зусиль по досягненню цілей і вирішення завдань. При оцінці ефективності управлінського лідерства насамперед аналізується здатність управлінського лідера бачити цілі і напрямки діяльності компанії. Ступінь ефективності управлінського лідерства визначається тим, наскільки сам лідер здатний генерувати ідеї і переводити їх в організаційні цілі, що ведуть до позитивного результату.

Висновки 3 проведеного дослідження. Таким чином, глобалізація та інформатизація суспільного розвитку трансформує інституційну природу лідерства в компаніях. Лідерство в управлінні організацією розглядається як складне поняття, яке відображає різноманіття управлінських процесів, а також плюралізм форм організацій. Лідерство може асоціюватися 3 людиною (його 
якостями, здібностями, орієнтацією на домінуюче становище в організації); процесом (взаємовідносинами і взаємодіями в організації за типом «ведучий - ті, яких ведуть») і продуктом (результатами діяльності індивіда).

В сучасних умовах феномен лідерства все більше співвідноситься 3 брендовою атрибутикою компанії. Лідерство позиціонується як навик і досвід. Технологія керівництва та лідерства повинна відповідати викликам ситуації, що склалася, творчо насичуватися рисами будь-яких стилів, які роблять лідерство ефективнішим. При цьому саме творча спрямованість керівника $€$ основною передумовою його високих лідерських якостей. В успішних компаніях розуміють, що лідерство - це управлінська компетенція, 3 якої можна вилучити прибуток, капіталізувати потенційні можливості в реальне ресурсне забезпечення. Для цього необхідно прищепити його великому колу співробітників, які згодом стануть ретрансляторами лідерських цінностей і правил поведінки.

1. Чеснокова Ж.А. Практические аспекты управления затратами на качество. Актуальные проблемы гуманитарных и естественных наук. 2016. № 12-2. С. 93-95. 2. Ричард Л. Дафт Уроки лидерства / под ред. И. В. Андреевой. Москва : Эксмо, 2006. 480 с. 3. Джеймс Дж. Клоусон. Лидерство третьего уровня. Взгляд в глубину. Альпина Паблишер, 2017. 519 с. 4. Robert Tannenbaum, Irving Weschler, Fred Massarik. Leadership and Organization : A Behavioural Science Approach. London, United Kingdom : Taylor \& Francis Ltd. 472 p. 5. Linda N. Jewell. Contemporary Industrial/organizational Psychology. 3rd ed. Pacific Grove, CA : Brooks/Cole Publishing Company, 1998. 622 p. 6. James Gibson, John Ivancevich, Robert Konopaske. Organizations: Behavior, Structure, Processes. 14th Ed. McGraw-Hill Education, 2011. 640 p. 7. John Newstrom. Organizational Behavior: Human Behavior at Work. 14th Edition. McGraw-Hill Education, 2014. 576 p. 8. James Kouzes, Barry Posner. The Leadership Challenge: How to Make Extraordinary Things Happen in Organizations. 6th Edition. Jossey-Bass. 2017. 356 p. 9. Кузес Джеймс М., Познер Барри. Управляй как бог. Экстраординарный менеджмент в компании / пер. с англ. В.С. Агеева. Москва : Из-во «Э», 2017. 400 с. 10. Яхонтова Е. С. Эффективность управленческого лидерства. Москва : ТЕИС, 2002. 501 с. 11. Таранавська Н. П., Пушкар Р. М. Менеджмент: теорія та практика : підручник. Тернопіль : Карт_бланш, 2003. 486 с. 12. Яхонтова E. C. Soft management, или управление отношениями в компании. Москва : Экономика, 2010. 470 с.

\section{REFERENCES:}

1. Chesnokova J. A. Prakticheskie aspektyi upravleniya zatratami na kachestvo. Aktualnyie problemyi gumanitarnyih i estestvennyih nauk. 2016. № 12-2. S. 93-95. 2. Richard L. Daft Uroki liderstva / pod red. I. V. Andreevoy. Moskva : Eksmo, 2006. 480 s. 3. Dzheims Dzh. Klouson. Lyderstvo treteho urovnia. Vzghliad v hlubynu. Alpyna Pablysher, 2017. 519 s. 4. Robert Tannenbaum, Irving Weschler, Fred Massarik. Leadership and Organization : A Behavioural Science Approach. London, United Kingdom : Taylor \& Francis Ltd. 472 r. 5. Linda N. Jewell. Contemporary 
Industrial/organizational Psychology. 3rd ed. Pacific Grove, CA : Brooks/Cole Publishing Company, 1998. 622 r. 6. James Gibson, John Ivancevich, Robert Konopaske. Organizations: Behavior, Structure, Processes. 14th Ed. McGraw-Hill Education, 2011. 640 r. 7. John Newstrom. Organizational Behavior: Human Behavior at Work. 14th Edition. McGraw-Hill Education, 2014. 576 r. 8. James Kouzes, Barry Posner. The Leadership Challenge: How to Make Extraordinary Things Happen in Organizations. 6th Edition. Jossey-Bass. 2017. 356 p. 9. Kuzes Djeyms M., Pozner Barri. Upravlyay kak bog. Ekstraordinarnyiy menedjment $\mathrm{v}$ kompanii / per. $\mathrm{s}$ angl. V. S. Ageeva. Moskva : Iz-vo «E», 2017. 400 s. 10. Yahontova E. S. Effektivnost upravlencheskogo liderstva. Moskva : TEIS, 2002. 501 s. 11. Taranavska N. P., Pushkar R. M. Menedjment: teoriya ta praktika : pidruchnik. Ternopil : Kart_blansh, 2003. 486 s. 12. YAhontova E. S. Soft management, ili upravlenie otnosheniyami v kompanii. Moskva : Ekonomika, 2010. $470 \mathrm{~s}$.

\section{Kozhushko L. F. [1; ORCID ID: 0000-0002-5724-4773], Doctor of Engineering, Professor at Management Department,

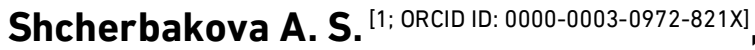 Candidate of Economics (Ph.D.), Associate Professor at Management Department \\ ${ }^{1}$ National University of Water and Environmental Engineering, Rivne \\ LEADERSHIP AS A PREREQUISITE FOR AN EFFECTIVE MANAGEMENT SYSTEM OF ORGANIZATION}

In the light of existing trends in modern social development (globalization, democratization, informatization) the focus on the role of the individual acquires a new significance. In the article has been grounded that leadership is the type of activity that permeates the entire management system and helps to achieve high organization' efficiency. Understanding the phenomenon of leadership is characterized by complexity, diversity and variability, so it does not allow for any unified definition. The multiplicity of the concept of «leadership» definitions is due to different approaches to the analysis of its subject. In the article a critical analysis of approaches to defining the concept of «leadership» has been performed. The author's definition of the «manager's leadership» concept is offered. Manager's leadership is the process in which the manager, as the leader of the organization, to achieve its goals together with its employees, creates a common vision of their future and organizes interaction, as well as involves organization's employees in these goals' implementation. The authors emphasize that in the study of the leadership' impact on the effectiveness of the organization, it is advisable to use the concept of «managerial leadership». Management leadership is manifested primarily as a process of improving the organizational culture, which allows you to develop elements that together ensure the effective operation of the company to achieve 
strategic goals. The concept of the managerial leadership' effectiveness has been proposed. It is proved that the effectiveness of managerial leadership, which is the basis of the organization's effectiveness, is determined by the ability to plan and implement changes in accordance with promising ideas and goals. The article highlights that successful companies understand that leadership is a managerial competence from which you can extract profits, capitalize on potential opportunities in real resources.

Keywords: leader; leadership; management; organization; managerial leadership; efficiency.

Кожушко Л. Ф. [1; ORCID ID: 0000-0002-5724-4773], д.Т.н., профессор кафедры менеджмента, Щербакова А. С. [1; ORCID ID: 0000-0003-0972-821X] к.э.н., доцент кафедры менеджмента

${ }^{1}$ Национальный университет водного хозяйства и природопользования, г. Ровно

\section{ЛИДЕРСТВО КАК ПРЕДПОСЫЛКА ЭФФЕКТИВНОЙ СИСТЕМЫ МЕНЕДЖМЕНТА ОРГАНИЗАЦИИ}

В статье обосновано, что лидерство является тем видом деятельности, который пронизывает всю систему управления и помогает достичь высокой эффективности в деятельности организации. В статье проведен критический анализ подходов к определению понятия «лидерство». Предложено авторское определение понятия «лидерство менеджера». Авторами подчеркнуто, что при исследовании влияния лидерства на эффективность работы организации, целесообразно применять понятие «управленческое лидерство». Предложена концепция эффективности управленческого лидерства и доказано, что эффективность управленческого лидерства, которое является основой эффективности деятельности организации, определяется способностью планировать и осуществлять изменения В соответствии с перспективными идеями и целями.

Ключевые слова: лидер; лидерство; менеджмент организация; лидерство менеджера; управленческое лидерство; эффективность. 